\title{
ANTIMICROBIAL ACTIVITY OF SOME ESSENTIAL OILS ON CANDIDA GENUS CLINICAL ISOLATES
}

\author{
Kryvtsova M.V. ${ }^{1}$, Kohuch T.T. ${ }^{1}$, Salamon I. $^{2}$, Spivak M.J. ${ }^{3}$ \\ ${ }^{1}$ Uzhhorod national university, 32 Voloshina str., Uzhhorod, 88000, Ukraine \\ ${ }^{2}$ University of Presov, 01 17th November str., Presov, 081 16, Slovakia \\ ${ }^{3}$ Zabolotny Institute of Microbiology and Virology, NAS of Ukraine, \\ 154 Akad. Zabolotny Str., Kyiv, 03143, Ukraine \\ e-mail:maryna.krivcova@gmail.com
}

\begin{abstract}
Aims. The purpose of the work was to study the qualitative composition of the concomitant opportunistic pathogenic microbiota in the patients suffering from pulmonary tuberculosis; analyze the sensitivity of the isolates to essential oils and antibiotics. Methods. For antibiotic susceptibility and antimicrobial activity testing was used disc diffusion method. The analysis of essential oils was carried out by Gas Chromatography method. Results. The study showed that microscopic Candida genus fungi were the dominating representative of the satellite microbiota isolated from the sputum - they were plated in $70 \%$ cases. Most of the strains, even antibiotic-resistant ones, were ascertained to be susceptible to the essential oil of Thymus vulgaris L. The essential oils of Hyssopus officinalis L. and Rossmarinus officinalis L. were shown to be characterized by moderate antibacterial activity. The sensitivity to Mentha piperita L. and Savlia officinalis L. was strain-specific. The essential oil of Matricaria chamomilla L. showed no antimycotic activity. Conclusion. By the level of antimycotic activity, the essential oils may be classified in a descending line beginning with Thymus vulgaris L. showing the most expressed antimicrobial activity, down to Hyssopus officinalis L., Rossmarinus officinalis L., Mentha piperita L., and Salvia officinalis L. The essential oil of Matricaria chamomilla L. showed no antimicrobial activity. The obtained results have proved the actuality of further studies of the impact of essential oils upon microorganisms, including those with multiple resistances to medical antibacterial preparations.
\end{abstract}

Keywords: Candida strains, essential oils, antibiotic resistant microoganisms, antimycotic activity.

The significance of opportunistic pathogenic bacteria in the development of inflammatory diseases and complications is shown to be continuously growing over the past several decades. Of them, spread of antibiotic-resistant agents of opportunistic infections has become a most burning problem [1].

Under such conditions, it becomes especially important to perform research aimed at the search for alternative anti-microbial materials. The sources for such materials are the plants that have for a long time been used in popular and traditional medicine. The plant-based materials, essential oils in particular, often demonstrate a high level of direct antimicrobial activity. Essential Oils (EOs) are complex natural mixtures of volatile secondary metabolites isolated from plant material (flowers, buds, seeds, leaves, twigs, bark, herbs, wood, fruits and roots) by hydro or steam distillation and by expression. The major components of EOs are mono and sesquiterpenes, as well as carbohydrates, 
alcohols, ethers, aldehydes and ketones which are responsible for the synergic interaction with antibiotics, due to that EOs antimicrobial activity can be attributed to inhibition or interaction with multiple targets in the microbial cell $[2,3]$. Essential oils, which are promising anti-bacterial remedies $[4,5]$ used in cosmetology, medicine, food industry, etc. [6]. The antimicrobial activity of essential oils are often related to their major components, even though the presence of minor compounds and the ratio between active constituents also play crucial role due to synergistic effect.

Another advantage for the use of plant-based material is their antioxidant and immunomodultaing activity, because resistance to such antimicrobialactive plant-based materials is formed much less frequently.

The contingent of TB patients receiving a protracted course of therapy with antibiotic and chemotherapeutic materials deserves serious attention as such that creates the preconditions for formation of antibiotic-resistant strains referred to the facultative microbiota of human organisms. At the same time, it is shown that the spread of complications caused by the not susceptible to antibiotic Candida genus fungi is presently taking on special significance.

The purpose of the work was to study the qualitative composition of the concomitant opportunistic pathogenic microbiota in the patients suffering from pulmonary tuberculosis; analyze the sensitivity of the isolates to essential oils and antibiotics.

Materials and methods. Our examination has been performed on the basis Microbiological laboratory of the Department of Genetics, Plant Physiology and Microbiology of Uzhhorod National University (Ukraine); Laboratory of Department of Ecology, Faculty of Humanities and Natural Sciences, University of Presov (Slovakia); Regional Clinicall Territial Medical Associaciation"Phthisiology", Uzhhorod (Ukraine).

Isolation of microorganisms. To detect the opportunistic pathogenic microorganisms, we performed a bacteriological study of the sputum of 40 pulmonary tuberculosis patients, viz.: to identify microscopic fungi - on Sabouraund Dextrose Agar (Himedia) medium; to identify streptococci and Neisseria - blood agar, Enterobacteriaceae - Endo agar (Farmaktiv, Ukraine). We identified the yeasts based on macromorphology, micromorphology, and physiological and biochemical tests [7].

Antibiotic susceptibility testing. For antibiotic susceptibility testing was used disc diffusion method according by EUCAST (Eurepean Committee on Antimicrobial Susceptibility Testing). Inoculum of Candida isolates was prepared from 24 hours old culture grown on Sabouraund Dextrose Agar (Himedia) and incubated $35 \pm 2{ }^{\circ} \mathrm{C}$. Colonies are suspended in $5 \mathrm{ml}$ of sterile $0,85 \%$ Saline. Yeast inocula $100 \mu \mathrm{L}$ in physiological solution were adjusted to the equivalent of $0.5 \mathrm{McF}$ arland standards and spread on the surface of SDA agar.

Sterile filter paper disks ( $6 \mathrm{~mm}$ in diameter) with Nystatin $(50 \mathrm{mcg})$, Itroconazole $(10 \mathrm{mkg})$, Fluconazole $(25 \mathrm{mcg})$, Ketoconazole $(10 \mathrm{mkg})$, Voriconazole $(1 \mathrm{mcg})$, Klotrimazole $(10 \mathrm{mrg})$, Miconazole $(50 \mathrm{mkg})$ were placed on the plate previously inoculated with a microbial suspension and incubated at $35 \pm 2{ }^{\circ} \mathrm{C}$ for $48 \mathrm{~h}$. Size of inhibition zone diameters surrounding filter papper disc was measured and compared to the Zone Diameter Interpretive Standards. 
Disc diffusion method. To determine the antimicrobial activity of essential oils as test cultures were used the typical strain of yeast from the American Type Culture Collection, USA Candida albicans ATCC 885-653; 19 clinical strains Candida isolated from the sputum of people with tuberculosis, which taken antibiotic therapy during long period. Antimicrobial activity was determined using disk diffusion method, using $6 \mathrm{~mm}$ sterilized filter paper discs $[7,8]$. Cultures of Candida were previously grown on the elective nutrient media Sabourand Dextrose Agar (SDA) $30^{\circ} \mathrm{C} 48 \mathrm{~h}$.

Sterile filter paper disks (6 mm in diameter) impregnated with $10 \mu \mathrm{L}$ of essential oil were placed on the SDA plate previously inoculated with a microbial suspension and incubated at $30{ }^{\circ} \mathrm{C} \pm 2{ }^{\circ} \mathrm{C}$ for $48 \mathrm{~h}$. The diameters of the inhibition zones were measured in millimeters including diameter of disc. Each antimicrobial assay was perfomed in at least triplicate.

The essential oils of the following plants were used: Rossmarinus officinalis L., Thymus vulgaris L., Menta piperita L., Matricaria chamomilla L., Hyssopus officinalis L., (produced by «Calendula», Nova Lubovna, Slovakia).

Isolation of the essential oil. Each sample of the plant parts with weight of $10 \mathrm{~g}$ was grounded in a blender. The essential oil from this raw-material were prepared by hydro-distillation ( $2 \mathrm{hrs}$ ) in a Clevenger-type apparatus according to the European Pharmacopoeia and a mixture of hexane and diethyl ether $(1: 1)$ was used as a collecting solvent. The essential oils stored under $\mathrm{N}_{2}$ at $+4{ }^{\circ} \mathrm{C}$ in the dark space before their composition identification.

GC-FID analyses. The analysis of the essential oils was carried out using the Gas Chromatograph Varian 3090, connected to MS Saturn 2100T integrator. The following operating conditions were used: capillary column: RX-5MS, $30 \mathrm{~m}$ x $0.250 \mathrm{~mm}$ i.d., film thickness: $0.25 \mu \mathrm{m}$, carrier gas: Helium, adjusted to a flux of $1.5 \mathrm{ml} / \mathrm{min}$, injection and FID-detector temperatures: $220{ }^{\circ} \mathrm{C}$ respectively $250{ }^{\circ} \mathrm{C}$, a capacity of sample injection: $2 \mu \mathrm{l}$, MS-detector with automatic injector type 1177.

Components were identified by their GC retention times, and the resulting values were comparable to those of literature. Oil component standards for comparison were supplied by Extrasynthese, Merck, Fulka, Sigma a Roth.

Statistical analysis. Results of experiment we used statistical solfware STATGRAPHIC with the calculation of averages (M) and their error (m), standard deviation $(\delta)$.

Results. The results of the bacteriological examination of the TB patients' sputum showed that opportunistic pathogenic microflora was isolated from the sputum of 30 patients, out of 40 examined. The study showed that microscopic Candida genus fungi were the dominating representative of the satellite microflora isolated from the sputum - they were plated in $70 \%$ cases. The microorganisms isolated from other patients were Neisseria genus bacteria (3 cases) and solitary cases of Escherichia coli, Pseudomonas aeruginosa, and Streptococcus genus bacteria. In two cases, bacterial and microscopic fungal associations Neisseria spp. + C. albicans; C. albicans + Aspergillus were identified.

The study revealed the high proportion of resistant strains among Candida sp. (tabl.1). 


\section{$\frac{\sqrt{0}}{\frac{0}{6}}$

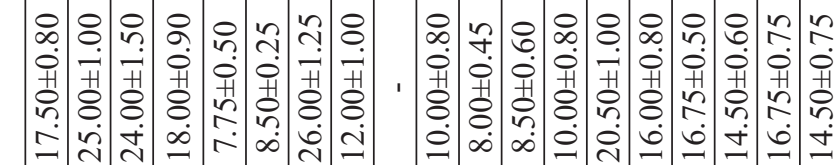

吾

$\because \frac{0}{\circ} \cong \infty$

ڤ.

吾

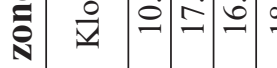

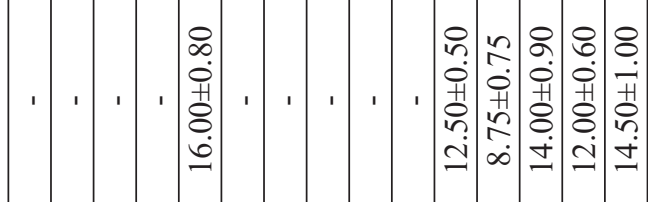

.

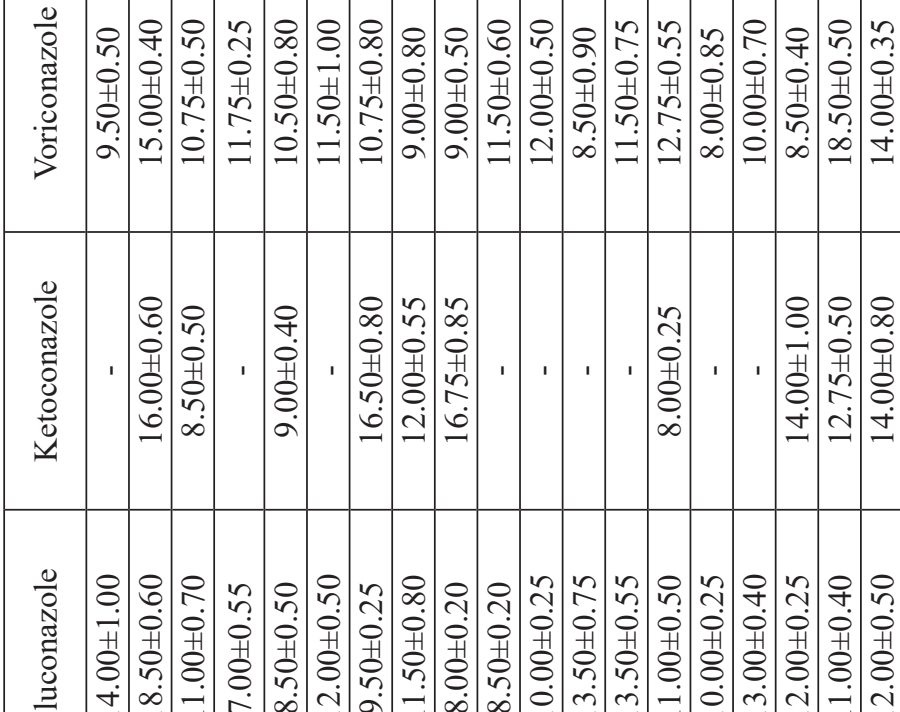

II

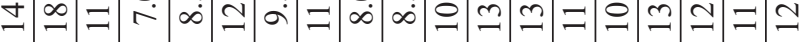

ป

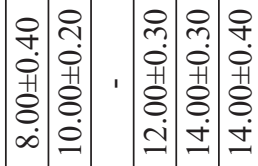

ㅇ․ㄴ.

ำ 융ำ

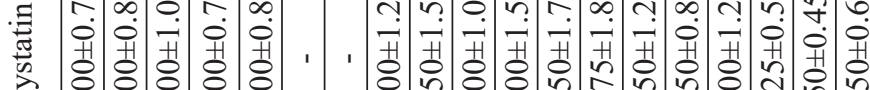

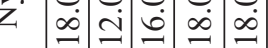

ปे

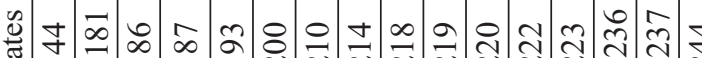

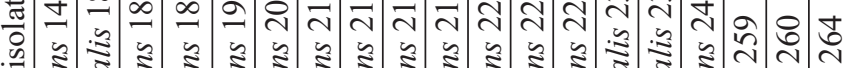

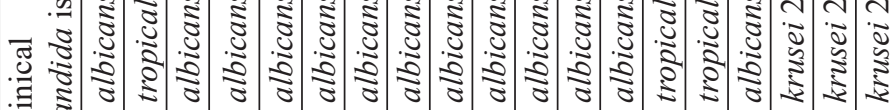

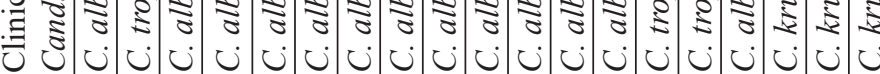


The microbial sensitivity test showed that 13 out of the 19 isolates were nystatin-sensitive; 3 isolates were low sensitive, 3 resistant. All isolates were resistant or low-sensitive to fluconazole and itraconazole; $90 \%$ strains were voriconazole-resistant. Only one of the 19 Candida strains was low sensitive to Fluconazole; all the rest were resistant to it: zones of growth retardation varied from $7.00 \pm 0.55$ to $18.50 \pm 0.60 \mathrm{~mm}$. As for Voriconazole, one strain proved sensitive; 2 low-sensitive; the others were resistant to that antibiotic material: maximum zone of growth retardation equaled to $15.00 \pm 0.40 \mathrm{~mm}$. No zones of growth retardation were identified in 14 isolates against Itroconazole; only 4 strains showed zones of growth retardation within $8.00 \pm 0.40$ to $14.00 \pm$ $\pm 0.40 \mathrm{~mm}$. No zones of growth retardation were identified in 9 isolates against Clotrimazole; however zones of growth retardation for Clotrimazole other 10 isoletes varied from $10.00 \pm 0.40$ to $18.75 \pm 0.50 \mathrm{~mm}$. The sensitivity of the isolates to Miconazole was somewhat higher: four strains had a sensitivity zone of 20 and more $\mathrm{mm}$, and only one strain was absolutely insensitive to the material. Eight strains were shown not to express sensitivity to Ketonazole; three strains were sensitive to the material. One isolate isolated from a patient with the recurrent disease was established to be resistant to all antibiotics tested; one was not sensitive or low-sensitive.

The study of susceptible of Candida genus fungi to antibiotics showed that resistance of the isolates did not depend upon the length of the patients' antibiotic treatment. Antibiotic-resistant isolates were detected in fresh patients as well as in those suffering from the recurrent disease. Other authors also showed cases of isolation of C. albicans to Nystatin, Fluconasole and Voriconazole isolated from faeces [7].

Antimicrobial activity of essential oils. According to results, it has been found that essential oils of Thymus vulgaris L. have significant antimicrobial activity to Candida spp. isolates: zones of growth retardation varied from $32.50 \pm 0.50$ to $75.00 \pm 1.50 \mathrm{~mm}$ (tabl. 2). What was more, all isolates were sensitive to the given essential oil, even those that were resistant to the antibiotics.

A little lesser effect was registered with application of Hyssopus officinalis L. and Rossmarinus officinalis L. Zones of growth retardation for the fungi isolates varied from 10 to $16 \mathrm{~mm}$. A certain antimycotic effect was observed with the use of Salvia officinalis L. however the sensitivity indices to this oil varied considerably. In particular, for this oil the smallest index was $7 \mathrm{~mm}$, and the biggest $12 \mathrm{~mm}$. Not all fungi isolates showed sensitivity to Menta piperita L. All yeast strains were resistant to essential oils of Matricaria chamomilla L., and neither of the strains showed any zones of growth retardation.

Chemical composition of EOs were as follows:

Rosmary essential oil (Rossmarinus officinalis L.): $\alpha$-pinene 19 $\pm 1 \%$; camphene $9 \pm 1 \%$; $\beta$-pinene $5 \pm 1 \%$; cineole $25 \pm 1 \%$; p-cymene $17 \pm 1 \%$; camphor $19 \pm 1 \%$; bornylacetate $<2 \%$; $\alpha$-terpineole $2.5 \pm 0.2 \%$; borneole $2.0 \pm 0.2 \%$.

Pippermint essential oil (Mentha piperita L.): limonene 2,5 $\pm 0,2 \%$; cineole $5.2 \pm 0.2 \%$; menthone $24 \pm 1 \%$; menthofuran $3.2 \pm 0.2 \%$; isomentone $3.8 \pm 0.2 \%$; menthyl acetate $4.1 \pm 0.2 \%$; isopulegol less than $0.1 \%$; menthol $39 \pm 1 \%$; pulegone $1.1 \pm 0.1 \%$; carvone $0.3 \pm 0.1 \%$; cineole $2.1 \pm 0.1 \%$. 


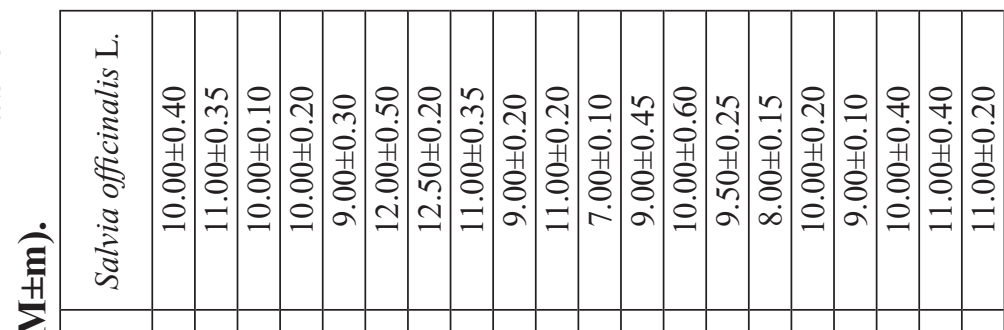

芚

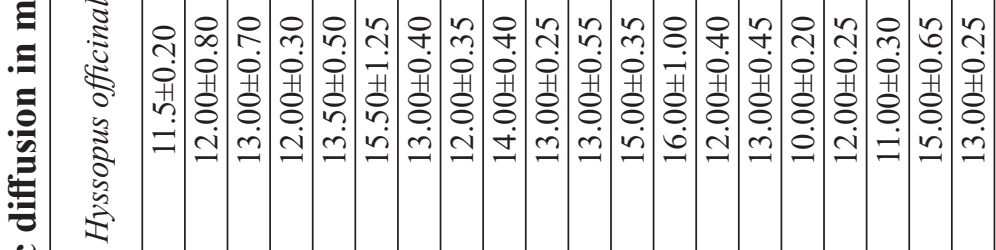

S)

(b)

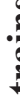

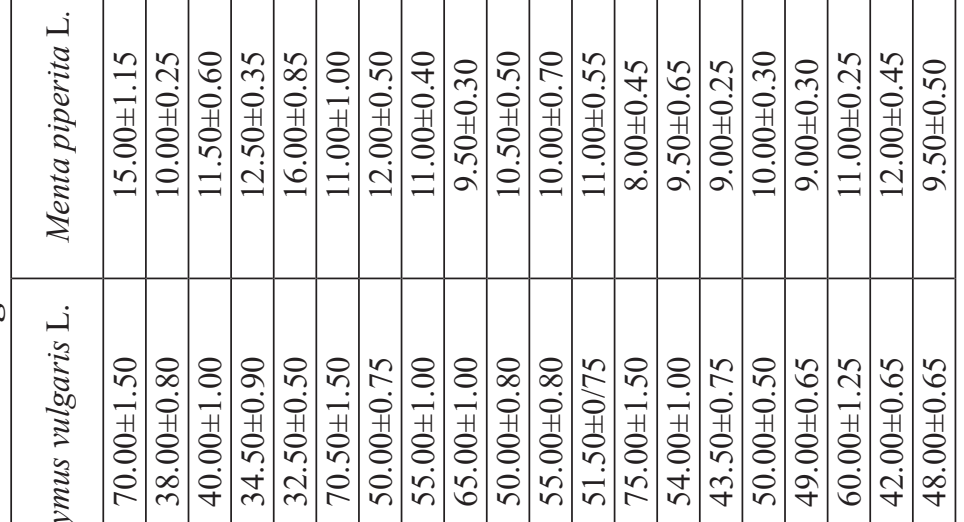

$\checkmark$

离

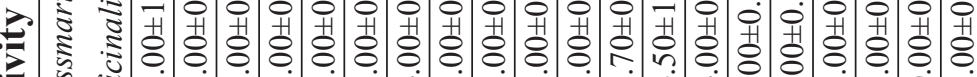

•

:

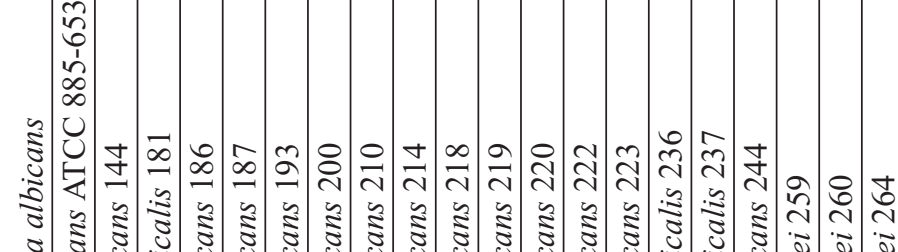

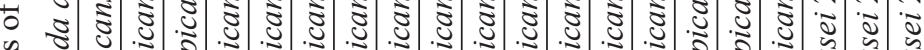

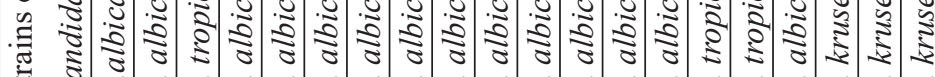

吾 
Thyme essential oil (Thymus vulgaris L.): p-cymene $40 \pm 2 \%$; thymol $32 \pm 2 \%$.

Matricaria oil (Matricaria chamomilla L.): bisabololoxides 6.0 $\pm 0.2 \%$; bisabolol $42 \pm 1 \%$; chamazulene $2.3 \pm 0.2 \%$; benzopyrene $<10 \mathrm{ppb}$.

Sage essential oil (Salvia officinalis L.): cineole $14 \pm 1 \%$; thujone $30 \pm 1 \%$; borneole $7.5 \pm 0.5 \%$.

Hyssop essential oil (Hyssopus officinalis L.): $\alpha$-pinene 15 $1 \%$; pinocampfene $35 \pm 2 \%$; isopinocampfene $20 \pm 1 \%$.

Discussion. The study revealed the high proportion of resistant strains among Candida sp. isolated from sputum of people with tuberculosis. According to results, it has been found that essential oils of Thymus vulgaris L., Menta piperita L., Rossmarinus officinalis L. have significant antimicrobial activity to Candida sp. Thereby, we have established the most distinguished antimycotic effect of essential oils of Thymus vulgaris L. According to other authors, the essential oil of this plant is also efficient against typical strains of C. albicans [9], Clostidium genus bacteria isolated from different places [10]. The results of the studies of other authors have pointed to sensitivity of microscopi fungi to essential oils of Satureja intermedia [11].

Most plants contain several compounds with antimicrobial properties for protection against aggressor agents, especially microorganisms. Active compounds found in some plants have antiseptic action; for example, thyme has thymol and carvacrol, clove has eugenol and isoeugenol, and oregano has carvacrol and terpineno. The action mechanisms of natural compounds are related to disintegration of cytoplasmic membrane, destabilization of the proton motive force, electron flow, active transport and coagulation of the cell content. Not all action mechanisms work on specific targets, and some sites may be affected due to other mechanisms. [12]. Nuzhat T. et all [13, 3] reported that antifungal activity of EOs can be attributed to the presence and synergism of some components such as carvacrol, $\alpha$-terpinyl acetate, p-cymene, thymol, pinene, linalool which have antimicrobial activity. Thymus oils and their components have presented fungicidal effect by disruption of cell membrane and suppression of germ tube formation. The study shows $[2,3]$ the effect of essential oils, including of thyme, upon biofilms. Carvacrol and thymol, two biocidal compounds, present in thyme (Thymus vulgaris L.) oil have an important antimicrobial effect on biofilms formed by S. aureus, S. epidermidis and Salmonella enterica serovar typhimurium. Also, Candida albicans, C. glabrata and C. parapsilosis biofilms were treated with carvacrol, geraniol and thymol producing inhibition in biofilm formation in $>75 \%$.

The obtained results have proved the actuality of further studies of the impact of essential oils upon bacterial isolates, including those with multiple resistances to medical preparations.

Conclusions. The study showed that microscopic Candida genus fungi were the dominating representative of the satellite microbiota isolated from the sputum - they were plated in $70 \%$ cases. According to results, it has been found that essential oils of Thymus vulgaris L. have significant antimicrobial activity to clinical Candida isolates. The essential oils of Hyssopus officinalis L. and Rossmarinus officinalis L. were shown to be characterized by moderate antibacterial activity. The sensitivity to 
Mentha piperita L. Ta Salvia officinalis L. was strain-specific. By the level of antimycotic activity, the essential oils may be classified in a descending line beginning with Thymus vulgaris L. showing the most expressed antimicrobial activity, down to Hyssopus officinalis L., Rossmarinus officinalis L., Mentha piperita L., and Salvia officinalis L. The essential oil of Matricaria chamomilla L. showed no antimicrobial activity.

Acknowledgments. The authors extend their appreciation to the firm «Calendula», Nova Lubovna, Slovakia.

Abbreviations used: EO (essential oil).

\title{
АНТИМІКРОБНА АКТИВНІСТЬ ДЕЯКИХ ЕФІРНИХ ОЛІЙ НА КЛІНІЧНІ ІЗОЛЯТИ РОДУ CANDIDA
}

\author{
Кривцова М.В. ${ }^{1}$ Когуч T.T. ${ }^{1}$, Саламон I. $^{2}$, Співак М.Я. ${ }^{3}$ \\ ${ }^{l}$ Ужгородський національний університет, \\ Волошина, 32, Ужгород, 88000, Украӥна \\ ${ }^{2}$ Пряшівський університет, 17 Листопада, 1, Прямів, 081 16, Словакія \\ ${ }^{3}$ Інститут мікробіології і вірусології ім. Д.К. Заболотного НАН України, \\ вул. Академіка Заболотного, 154, Київ, 03143, Україна \\ Резюме
}

Мета. Вивчити склад умовно патогенної супутньої мікробіоти у хворих на туберкульоз легень та визначити чутливість ізолятів до ефірних олій та антибіотиків. Методи. Чутливість мікроорганізмів до антибіотиків та антимікробну активність ефірних олій визначали з використанням диско- дифузійного методу. Біохімічний склад ефірних олій визначали методом газової хроматографії. Результати. Дослідження показали, що домінуючими представниками супутньої мікробіоти, ізольованої з мокроти хворих на туберкульоз, були мікроскопічні гриби роду Candida, які виділяли у 70 \% випадків. Встановлено, що більшість штамів, навіть антибіотикорезистентних, були чутливими до ефірної олії Thymus vulgaris L. Помірною антибактеріальною активністю характеризувались ефірні олії Hyssopus officinalis L. та Rossmarinus officinalis L. Чутливість до Mentha piperita L. і Salvia officinalis L. була штамоспецифічною. Антимікозної активності ефірної олії Matricaria chamomilla L. не виявлено. Висновки. За рівнем антимікотичної активності ефірні олії можна розмістити у ряді зниження протимікробної дії від Thymus vulgaris L., що характеризувалась найвиразнішою антимікробною активністю, до Hyssopus officinalis L., Rossmarinus officinalis L., Mentha piperita L., Salvia officinalis L. Отримані результати вказують на актуальність подальших досліджень впливу ефірних олій на мікроорганізми, у тому числі з множинною резистентністю до антибактеріальних лікарських препаратів.

Ключові слова: Candida, ефірні олії, антибіотикорезистентні мікроорганізми, антимікозна активність. 


\title{
АНТИМИКРОБНАЯ АКТИВНОСТЬ НЕКОТОРЫХ ЭФИРНЫХ МАСЕЛ НА КЛИНИЧЕСКИЕ ИЗОЛЯТЫ РОДА СANDIDA
}

\author{
Кривцова М.В. ${ }^{1}$, Когуч Т.Т. ${ }^{1}$ Саламон И. ${ }^{2}$, Спивак Н.Я. ${ }^{3}$ \\ ${ }^{1}$ Ужсгородский национальный университет, \\ ул. Волочина, 32, Ужгород, 88000, Украина \\ ${ }^{2}$ Прешовский университет, 17 Ноября, 01, Прешов, 081 16, Словакия \\ ${ }^{3}$ Институт микробиологии и вирусологии им. Д.К. Заболотного НАН Украинь,, \\ ул. Академика Заболотного, 154, Киев, 03143, Украина

\section{Резюме}

Цель. Изучить состав сопутствующей условно патогенной микробиоты у больных туберкулезом легких и определить чувствительность изолятов к эфирным маслам и антибиотикам. Методы. Чувствительность микроорганизмов к антибиотикам и антибактериальную активность эфирных масел изучали диско-диффузионным методом. Биохимический состав эфирных масел определяли методом газовой хроматографии. Результаты. Исследования показали, что доминирующими представителями сопутствующей микробиоты, изолированной из мокроты больных туберкулезом, были микроскопические грибы рода Candida, которые выделяли в 70 \% случаев. Показано, что большинство штаммов, в том числе антибиотикорезистентные, были чувствительны к эфирному маслу Thymus vulgaris L. Умеренной антибактериальной активностью характеризовались эфирные масла Hyssopus officinalis L. и Rossmarinus officinalis L. Чувстивтельность к Mentha piperita L. и Salvia officinalis L. была штаммоспецифической. Антимикозной активности эфирного масла Matricaria chamomilla L. не обнаружено. Выводы. По уровню антимикотической активности эфирные масла можно разместить в ряду снижения антимикробного действия от Thymus vulgaris L., характеризующегося наиболее выраженной антимикробной активностью, до Hyssopus officinalis L., Rossmarinus officinalis L., Mentha piperita L., Salvia officinalis L. Полученные результаты указывают на актуальность дальнейших исследований влияния эфирных масел на микроорганизмы, в том числе с множественной устойчивостью к антибактериальным лекарственным препаратам.

Ключевые слова: Candida, эфирные масла, антибиотикорезистентные микроорганизмы, антимикозная активность.

1. Yoko F, Franklin D. Lowy Antimicrobial-resistant bacteria in the community setting. Nature Reviews Microbiology. 2006; 4 : 36-45. doi:10.1038/nrmicro1325

2. Kalemba D, Kunicka A. Antibacterial and antifungal properties of essential oils. Curr. Med. Chem. 2003; $10: 813-829$.

3. Bueno J, Demirci F, Husnu Can. K. Essential Oils against Microbial Resistance Mechanisms, Challenges and Applications. Chapter: 6. In Rai M, Zacchino S, Derita M.G. editors Essential Oils and Nanotechnology for Treatment of Microbial Diseases. 2017. CRC Press; 2017. p. 143-158. doi: 10.1201/9781315209241-8

4. Kryvtsova M, Rivis O, Babenko L, Spivak N, Nikolaichuk V, Ganic T. Antibacterial properties of essential oils against specific opportunistic pathogenic bacteria. In: Proceedings of $2^{\text {nd }}$ Japan - Turkey International Symposium on Pharmaceutical and Biomedical Sciences (JATUSPAB-2). 2017; Sep 11-12, Trabzon, Turkey. p. 30. 
5. Kačániová M, Terentjeva M, Vukovic N, Puchalski C, Roychoudhury S, Kunová S, Klūga A, Tokár M, Kluz M, Ivanišová E. The antioxidant and antimicrobial activity of essential oils against Pseudomonas spp. isolated from fish. Saudi Pharmaceutical Journal. 2017; 25(8): 1108-1116. doi.org/10.1016/j.jsps.2017.07.005

6. Özer E, Kara HH. Antimicrobial properties of essential oils and their potential applications in milk and dairy products. In: Abstract book of The third International Mediterranean Symposium on Medicinal and Airs General Directorate of Foresromatic Plants (MESMAP-3); 2017 Apl 13-16; Girne-Turkish Republic of Northern Cyprus. Pub. Republic of Turkey Ministry of Forestry and Water Affairs General Directorate of Forestry, 2017. p. 149.

7. Maroszynska M, Kunicka-Styczynska A, Rajkowska R. Antibiotics sensitivity of Candida clinical and food-borne isolates. Acta biochimica polonica. 2013; 60: 719-724.

8. Rhos JL, Recio MC. Medicinal plants and antimicrobial activity. Journal of Ethnopharmacology. 2005; 100(1-2):80-84. doi:10.1016/j.jep.2005.04.025

9. Borugă O, Jianu C, Mişcă C., Golet I, Gruia AT, Horhat FG. Thymus vulgaris essential oil: chemical composition and antimicrobial activity. J. Med Life. 2014; 7(Spec Iss 3): 56-60.

10. Kačániová M, Vukovič N, Horská E, Šalamon I, Bobková A, Hleba L, Mellen M, Vatlák A, Petrová J, Bobko M. Antibacterial activity against Clostridium genus and antiradical activity of the essential oils from different origin. Journal of Environmental Science and Health, Part B: Pesticides, Food Contaminants, and Agricultural Wastes. 2013; 49(7): 505-512. doi: 10.1080/03601234.2014.896673.

11. Mey C.A, Sharifi-Rad Javad, Sharifi- Mehdi Rad, Seyedeh Mahsan, Hoseini-Alfatemi, Marcello Iriti, Majid Sharifi-Rad and Marzieh Sharifi-Rad Int. Composition, Cytotoxic and Antimicrobial Activities of Satureja intermedia Essential Oil. J. Mol. Sci. 2015; 16: 17812-17825; doi:10.3390/ijms160817812.

12. Silva N, Fernandes Junior A. Biological properties of medicinal plants: a review of their antimicrobial activity. J. Venom. Anim. Toxins incl. Trop. Dis . 2010; 16 (3): 402-413. http://dx.doi.org/10.1590/S1678-91992010000300006.

13. Nuzhat T, Vidyasagar G.M. Antifungal investigations on plant essential oils. A review. Int. J. Pharma. Pharma. 2013; 5 (2); 19-28.

Отримано 18.03. 2018 